\title{
The Philippines context for marine tenure and small-scale fisheries
}

\author{
Robert Pomeroya ${ }^{a}$ Catherine A. Courtney ${ }^{b}$ \\ a Connecticut Sea Grant, University of Connecticut, 1080 Shennecossett Road, Groton, CT \\ 06340, USA \\ ${ }^{b}$ Tetra Tech Inc., 737 Bishop St., Honolulu, HI, USA
}

\section{Abstract}

The Philippines has had a long and evolving history in marine tenure and marine resource management. This ranges from traditional tenure rights to some of the first community based fisheries tenure systems in the world to a legal system which supports marine tenure. Secure marine tenure and improved governance are enabling conditions for supporting sustainable small-scale fisheries to meet multiple development objectives. This article provides an overview of the Philippines context for marine tenure and small-scale fisheries. The article discusses both government and non-governmental initiatives on marine tenure. Recommendations are made to strengthen the current legal, policy and practical context of marine tenure in the Philippines in order to support sustainable small-scale fisheries.

This is the accepted manuscript of a paper published in Marine Policy. The final version may be accessed at https://doi.org/10.1016/i.marpol.2018.05.030.

\section{Introduction}

Tenure refers to the relationship (whether defined under formal de jure law, customary law, or traditional practice) that individuals and groups hold with respect to resources on land and at sea $[1,2]$. Marine tenure involves establishing a set of rights and responsibilities in the marine and coastal environment as to who is allowed to use which resources, in what way, for how long, and under what conditions, as well as who is entitled to transfer rights (if any) to others and how [1-5]. Charles [5,6] states that fishery tenure is closely related to the idea of use rights - 'the right to use' fishery resources, as recognized or assigned by the relevant management authority, whether formal or informal.

Secure marine tenure and improved governance are enabling conditions for supporting sustainable small-scale fisheries to meet multiple development objectives if investment constraints are addressed and programming opportunities are seized. The UN FAO Voluntary Guidelines on Securing Sustainable Small-Scale Fisheries in the Context of Food Security and Poverty Eradication (SSF Guidelines) [7] highlight the important role of national governments and small-scale fishers in achieving responsible governance of tenure within an integrated and ecosystem-based approach to management. The SSF Guidelines urge States to adopt national legislation that ensures small-scale fishers, fish workers, and their communities have secure, equitable, and socially and culturally appropriate tenure rights to fishery resources, fishing 
areas, and adjacent land. Small-scale fishers should be granted preferential access to fish and water through the creation and enforcement of exclusive use zones. Effective and transparent mechanisms to address resource use conflicts must be in place to protect the rights of smallscale fishers.

Small-scale fishers and coastal communities with secure rights over a given fishing area have a strong interest in organizing and acting collectively to manage their resources sustainably [2]. Tenure refers to the relationship (whether defined under formal de jure law or under customary law) that individuals and groups hold with respect to natural resources. Marine tenure involves establishing a set of rights and responsibilities in the coastal and marine environment as to who is allowed to use which resources, in what way, for how long, and under what conditions, as well as who is entitled to transfer rights to others and how. Formal recognition of marine tenure provides communities with the security that they can invest in and manage their fishery resources for long-term sustainability. Marine tenure needs a strong governance framework and institutions at both national and local levels to maintain secure tenure rights [8].

The responsible governance of marine tenure involves respecting the rights of small-scale fishers and fishing communities to the resources that form the basis of their social and cultural well-being, their livelihoods and their sustainable development. National legal and policy frameworks, administrative and judicial systems, effective community-based and comanagement arrangements, dispute resolution mechanisms, local participation and empowerment, and strengthened institutional capacity are all key ingredients of responsible governance of marine tenure.

The Philippines has had a long and evolving history in marine tenure and marine resource management. This ranges from traditional tenure rights to some of the first community based fisheries tenure systems in the world to a legal system which supports marine tenure. Government, non-governmental organizations, donors and fishers have all supported secure tenure rights for sustainable fisheries. This article provides an overview of the Philippines context for marine tenure and small-scale fisheries. The article discusses both government and non-governmental initiatives on marine tenure. Recommendations are made to strengthen the current legal, policy and practical context of marine tenure in the Philippines in order to support sustainable small-scale fisheries.

\section{An historical overview of marine tenure in the Philippines}

The island settlers of what would become the Philippines had a long history of traditional fishing rights before the archipelago was first colonized by Spain in the 17th century. The barangay (village) had jurisdiction over coastal resources and fishery limits were defined by them [9]. The traditional property rights of barangays over fishing grounds were steadily eroded during the long Spanish colonial period, with community authority and rights superseded by state government control [10]. Lopez [11] reports that under Spanish rule, the barangays were eliminated as administrative entities and with them went the territorial fishing rights claimed by each village. Under Spanish law, the fisheries and other natural resources were declared to 
be held by the Crown. Under both the Spanish and the Americans, traditional authority and rights were superseded by municipal government control of local fishing grounds. This administrative structure of municipal authority remains in place in the country today. Despite the historical existence of traditional fishing rights and village-based management systems in the Philippines, for the most part these systems have disappeared in the country. This is not to say that traditional community-based resource management systems, and informal fisheries rights and rules systems do not exist, for localized examples can be found throughout the country $[12,13]$.

The threat of Japanese encroachment moved the government to finally pass a Fisheries Law in 1932, restricting commercial fishing activities to American and Filipino-owned corporations. For the first time, municipal waters were defined as up to $5.5 \mathrm{~km}$ from shore; municipal governments now had authority to grant licenses to commercial fishers within these waters. The 1960s and 1970s saw a period of industrialization [14]. In the 1960s, the Philippine government, aided by Japanese advisors, undertook intensive infrastructure, technology, extension and credit programs through the Fisheries Development Program to 'develop' the industry [15]. In the early 1970s, the country fell under Martial Law and the centralized government control of fisheries was further reinforced through Presidential Decree (PD) 704, otherwise known as the Fisheries Act of 1975. Under PD 704, fisheries management is the responsibility of the government, both national and municipal. The management measures (mainly through regulatory instruments) undertaken by the government during this time, however, were ineffective in promoting the sustainable development and management of the country's fisheries. In the mid-1970s, in response to decreasing unit catch of small-scale fishers, the government embarked on fishery policies and development programs concentrated on 'use orientation,' that is, increasing production and exploitation of the resource base. In the 1980s, the government continued to support the needs of the sector through the Expanded Fish Production Program (EFPP) from 1983 to 1987. In the small-scale fisheries sector, the strategy of the program was geared towards enabling the small fishers to venture into deeper waters by equipping them with more efficient boats and fishing gears. The underlying assumption was that the fishery could support increased fishing effort, despite expert opinion as early as 1980 that it could not. Ironically, it was during this period (1984-1988), that there was a decreased rate in coastal fish production of $1.3 \%$ a year, compared to the increasing rate of $6.1 \%$ in the preceding five years from 1979 to 1983 [16,17]. Overfishing decreased returns to fishers and conflicts over resource access and use increased [18]. The problems in the fishery continued to worsen throughout the late 1980s and early 1990s. The management (mainly through regulatory instruments) and development (increased fishing effort) measures undertaken by the government were still ineffective in promoting the sustainable management and development of the country's fisheries. It was realized that with the increasing rate of deterioration of natural resource systems in the Philippines, there was no way the country could pursue a pathway of sustainable development.

The right to use fishery resources for subsistence is enshrined in the Philippine Constitution. The ocean area of the Philippines is an open access resource. Management of local fishery resources is considered not only a responsibility but also a right. Though this right is more 
enthroned to the local government rather than fishing communities by the Fisheries Code, it is evident that the spirit of the law is to devolve powers to manage the coastal resources to the fishers. The legal framework does not clarify/define the designated tenure area or the management mechanism for governance.

The 1998 Fisheries Code is considered a breakthrough in fisheries legislation because it "reinforces" the management of municipal waters originally devolved through the 1991 Local Government Code from national to local governments. Organized community members are given the opportunity to formally participate in management efforts through, among others, the Fisheries and Aquatic Resources Management Councils (FARMCs). Legal instruments, such as the Certificate of Ancestral Domain Title and Mangrove Stewardship Contracts, now also exist to give coastal communities a semblance of tenure security. These instruments likewise encourage communities to take charge of resource management planning and implementation. Tenure rights are imperative in ensuring that fishing communities obtain permanent, exclusive rights over the resources in a specific area, that fickle politics or legislation will not eventually deprive them of the long-term benefits of their management efforts $[19,20]$.

Case studies in the Philippines have shown that when user rights are specified and secure, there is a change in the behavior and attitude of the resource user towards conservation, and a much greater chance that sustainability will be achieved and maintained [21,22].

\section{Marine tenure and national laws and policies}

The marine tenure and fisheries management narrative has undergone several transitions in the Philippines, as outlined by the following broad themes [23]:

- 1970s-early 1980s: Command and control

- 1980s: Community-based management

- 1980s-1990s: Coastal resource management

- 1990s: Co-management

- 2000s: Integrated fisheries management

- 1990s-2000s: Marine protected area management

- 2010s: Ecosystem approach to fisheries management (EAFM)

Starting in the 1960s, alternative methods of resource use and management were explored in an attempt to reverse the negative trends of resource degradation in the Philippines.

Consequently, there has been a shift to forward-looking policies and strategies that advocate 'resource management' over a 'use orientation' through community-based initiatives to rehabilitate, conserve and protect the resources based on use and enhancement of local knowledge, skills, responsibility and accountability [24]. The irrigation sector was the first to evolve an institutional development scheme for mobilizing the active participation of water users in 1968. People-oriented programs in the forestry sector started in the early 1970s [25]. Community-based coastal resource management (CBCRM) started in the mid-1980s. To date, well over 1000 CBCRM projects have been implemented by government, NGOs, fishing 
communities, and academic and research institutions. No country in the world has the range of experience with CBCRM and co-management as exists in the Philippines [21]. The transition from CBCRM to co-management in the Philippines began in the early 1990s as project implementers, NGOs, fishers and academics and researchers realized that the focus on community organizing and empowerment of fishers would not be enough to support resource management. It was realized, especially after enactment of the Local Government Code of 1991, that the local government was needed as a partner to provide legal and enforcement support for the community resource management and marine protected areas. CBCRM became an integral part of co-management.

The efforts in CBCRM and co-management in the Philippines emanate from the government, NGOs and international development agencies (Table 1). In 1989, President Aquino created a Presidential Commission on Anti-illegal Fishing and Marine Conservation or the Bantay Dagat Committee, which called for increased coordination among government agencies in enforcement of fisheries laws and increased participation of fishers in management [10]. In 1991, the government recognized the need to increase participation in management and to devolve control over resource access to local levels through policy and institutional reforms. Through several initiatives, the government actively promoted devolution and communitybased resource management and co-management efforts to conserve the coastal resources and diversify the income sources of the low-income small-scale fishers. These initiatives for CBCRM were embodied in the 1993-1998 Medium-Term Philippine Development Plan (MTPDP). Among its strategies were to: implement a community-based fishery management strategy; regulate fishing effort within maximum sustainable yields; promote territorial use rights for small fishers; intensify aquaculture, optimal utilization of offshore, deep sea resources; and provide diversified occupational opportunities among marginal fishers. The core program for fisheries implemented under the plan was the Fisheries Sector Program (FSP) from 1990 to 1995. Among the policy and institutional reforms instituted through the FSP were: (1) decentralization of authority and simplification of procedures for clearance of local fisheries management ordinances subject to national laws and/or policies; (2) strengthening the enforcement of fisheries laws through municipal-based inter-agency law enforcement teams; (3) promotion of community-based initiatives to rehabilitate, conserve and protect the coastal resources and to diversify the sources of income of small-scale fishers; (4) NGOs engagement to assist and undertake community organizing; and (5) shift to limited access in concerned fishing areas. At the core of the resource and rehabilitation thrust of the FSP was coastal resource management. Fishers, local government, units and other concerned agencies in the area were given the opportunity to determine the specific problems in their areas and to identify the management strategies to counteract these problems. These activities were continued through a follow-up project called the Fisheries Resources Management Project (FRMP). Subsequent projects in the Philippines, primarily funded by USAID, such as the Coastal Resource Management Project (CRMP), the Fisheries Improvement for Sustainable Development (FISH) project, and the Ecosystems Improved for Sustainable Fisheries (ECOFISH) project, have continued to build on these reforms and approaches emphasizing an ecosystem approach to fisheries management. 
Table 1: National laws and policies in support of marine tenure in the Philippines.

\begin{tabular}{|c|c|c|c|}
\hline Law or Policy & $\begin{array}{l}\text { Year } \\
\text { implemented }\end{array}$ & Relation to marine tenure & Reference \\
\hline Local Government Code RA 7160 & 1991 & $\begin{array}{l}\text { Devolution to local } \\
\text { government; } \\
\text { Municipal waters; } \\
\text { Preferential rights }\end{array}$ & 26,27 \\
\hline Fisheries Code RA 8550 & 1998 & Municipal waters & \multirow[t]{2}{*}{$29-31$} \\
\hline Amended Fisheries Code RA 10654 & 2015 & Preferential rights; FARMCs & \\
\hline $\begin{array}{l}\text { National Integrated Protected Areas System Act RA } \\
7586\end{array}$ & 1992 & Protected areas & 32 \\
\hline Integrated Coastal Management EO 533 & 2006 & $\begin{array}{l}\text { Consultative integrated coastal } \\
\text { management }\end{array}$ & 33 \\
\hline \multicolumn{4}{|l|}{ Indigenous People's Rights: } \\
\hline - $\quad$ Philippines Constitution & 1987 & Rights to ancestral lands & \multirow[t]{3}{*}{$34,35,40$} \\
\hline $\begin{array}{l}\text { - Certificate of Ancestral Domain Claim (DENR } \\
\text { AO 2) }\end{array}$ & 1993 & $\begin{array}{l}\text { Rights to manage and use } \\
\text { resources on ancestral lands }\end{array}$ & \\
\hline - $\quad$ Indigenous People's Rights Act RA 8371 & 1997 & Protection of ancestral rights & \\
\hline Mangrove Forests: DENR EO 263 & 1995 & Forest management agreement & 44 \\
\hline Foreshore lands: Fisheries Code RA 8550 & 1998 & Lease agreement & 45 \\
\hline Fisherfolk settlement: Fisheries Code RA 8550 & 1998 & $\begin{array}{l}\text { Establishment of fisherfolk } \\
\text { settlement }\end{array}$ & 29,30 \\
\hline \multicolumn{4}{|l|}{ Marine Protected Areas: } \\
\hline - $\quad$ Fisheries Code RA 8550 & 1998 & $\begin{array}{l}\text { Establish and manage an MPA } \\
\text { or fish sanctuary }\end{array}$ & 46 \\
\hline - $\quad$ NIPAS RA 7586 & 1992 & & \\
\hline $\begin{array}{l}\text { Autonomous Region of Muslim Mindanao (Muslim } \\
\text { Mindanao Autonomy Act } 86 \text { or ARMM } \\
\text { Aquatic and Fisheries Code) }\end{array}$ & 1999 & $\begin{array}{l}\text { Manage and protect fisheries } \\
\text { and aquatic resources }\end{array}$ & 47 \\
\hline
\end{tabular}

\subsection{Local Government Code of 1991}

In 1991, the Philippine government enacted into law the Local Government Code (LGC) (Republic Act No. 7160) which devolved the delivery of public services and other administrative activities to local government units (LGU) (province, city, municipality, barangay). The LGC marked a shift in public administration from a centrally driven system of 'top-down' management to a 'bottom-up' strategy of expanded participation and responsibility of the LGUs. All matters under the Local Government Code are governed and controlled by the LGUs, Governors, Congressmen, and Mayors. Local government code empowers all LGUs to manage their respective municipalities, except for national heritage parks and protected areas. Among the functions devolved to the LGUs were resource management and environmental protection. National agencies were now required to consult with local leaders in the design of development programs. A general operative principle was a provision that the LGUs may group themselves, consolidate or coordinate their efforts, services and resources for purposes commonly beneficial to them. The LGUs were given broad powers to generate funds through local taxes or shares in revenue from the exploitation of resources that used to be at the disposal of the national government. The LGC granted local governments (municipalities) with a number of powers including the management of municipal or nearshore waters. LGUs are responsible for the regulation of all fisheries within the municipal waters, including vessels of less than 3GT and fishing within the $15 \mathrm{~km}$ from shore. The national government has no influence on how natural 
resources are managed within municipal jurisdiction. Section 35 of the LGC specifically states that LGUs may enter into joint ventures and such other cooperative arrangements with people's organizations (An organized group of people (fishers, farmers, women, etc.)) and nongovernmental organizations to engage in the delivery of certain basic services, capacity building and livelihood projects, and to develop local enterprises designed to diversify fisheries, among others.

Section 2 (c) of the LGC mandates the participation of stakeholders in coastal resource management programs and projects. The law requires all national agencies and offices to conduct periodic consultations with non-governmental and people's organizations and other concerned sectors of the community before any project or program is implemented.

The LGUs and local communities were also given certain privileges and/or preferential rights. Municipalities have the exclusive authority to grant fishery privileges and establish zones in municipal waters and impose rentals, fees and charges. According to Section 149 of the LGC, municipalities (and cities, under Section 151), through the Sangguniang Bayan, may grant fishery privileges or rights to organizations or cooperatives of marginal fishers to erect fish corrals; oyster, mussel or other aquatic beds; or bangus fry gathering areas within a definite zone of the municipal waters free of any rental, fee or charge [26,27]. Granting fishery privileges within definite zones and establishing fishery refuge and sanctuaries entail the establishment of zones within municipal waters.

A Comprehensive Land Use Plan (CLUP) for each municipality and province is required by law via the LGC (1991) and is a prerequisite to the formation of local or provincial development plans [28]. CLUP refers to the primary and dominant bases for land use, applying a rational approach for allocating available land resources as equitably as possible among competing user-groups and for different functions, consistent with the development plan of the area. The CLUP is often weak in LGUs. Likewise, the CLUP is not always developed in remote areas because of the lack of a formal process and thorough understanding of the natural and socioeconomic resources in remote areas.

LGUs have considerable freedom in interpreting the law as it relates to small-scale fisheries and municipal waters, especially because the fisheries law usually provides only general guidance, rather than detailed instruction on how to implement it. LGUs are interested in integrated coastal management, which includes habitat protection, shoreline management, mangrove restoration, tourism development, etc. Progressive mayors almost always support programs that tend to protect local resources, but only a handful of local leaders are considered progressive.

However, it has not been easy for the LGUs to manage fisheries and the rule of law varies substantially, depending on the will and capacity of mayors. While many mayors welcomed new rights, they can't rely heavily on the national government for support. Many local governments were not prepared or were unaware of their new roles. Limited resources were made available to them from the national government for the transition, and it has taken them a considerable 
time to adjust to their new authority. Many LGUs have not made any progress, while some have actively engaged in supporting fisher organizations and local management measures. LGUs' capacity and education are limiting factors in interpreting and implementing the law.

BFAR and LGUs do not work together in a streamlined fashion, partly due to the autonomy of municipalities. Each LGU can adapt its own system, which is not compatible with other entities either at the national or local level. Problems and inconsistencies become quite obvious, even around otherwise straightforward processes such as vessel registration, traceability monitoring, and catch reporting.

For LGUs, often capacity and education are limiting factors in interpreting and implementing the law. Fisheries law usually provides only general guidance, rather than detailed instruction on how to implement it. As a consequence, the interpretation and practice of implementation can substantially differ between LGUs. Thus, the effectiveness of fisheries law mainly depends on the influence, will, and capacity of the LGU administration and its leaders.

The challenge of harmonizing a national, centralized system while engaging local and community-based organizations is the most important factor that must be considered. Since small-scale fisheries are within LGUs, the jurisdiction and enforcement of marine resource policies varies from each city/municipality because of personal capabilities or bias of LGU leaders. The mayor's will and the organizational level of the individual LGUs are important. However, alignment on fisheries issues between municipalities is currently insufficient. It is therefore important that there is a national governing agency/policy or an oversight body that will ensure enforcement of important policies at the local levels.

\subsection{Fisheries Code of 1998}

In 1998, Republic Act No. 8550 or the Philippine Fisheries Code was signed into law [29]. Part of the Code consolidates existing laws and guidelines previously scattered among presidential decrees, administrative orders, and local ordinances into a single consistent law regulating fishing and the protection of the aquatic environment. Under the Fisheries Code, several sections of the LGC were clarified and supported. The Code clarified the designation of municipal waters up to $15 \mathrm{~km}$ for shore and the granting of preferential rights to fishing privileges in municipal waters to registered fisher organizations and cooperatives. This definition helped to resolve longstanding conflicts between small-scale and commercial fishing. Specifically, fishing rights are granted by LGUs within their municipal waters (up to $15 \mathrm{~km}$ from the coastlines under the Fisheries Code) or special agencies created by law to administer select bodies of water (e.g., Laguna Lake Development Authority, Palawan Council for Sustainable Development). Fishing rights are granted to municipal fishers and their organizations listed in the registry of municipal fishers, subject to certain conditions and limitations. Fishpond licenses are required under the Fisheries Code, with preference given to small or medium enterprises, for up to 50 ha for individuals and 250 ha for associations/enterprises, subject to certain conditions. 
In addition, the Fisheries Code called for the establishment of FARMCs at national and municipal/city levels to provide a structure for public participation in coastal and marine resource management (Section 69 and 73, RA 8550). The FARMCs are formed among fisher organizations and cooperatives and NGOs with assistance from the LGU and government agencies. The FARMCs are mandated to carry out a number of management advisory functions in close collaboration with the LGU. These functions include assisting in the preparation of Municipal Fishery Development Plans, recommending the enactments of fishing ordinances, assisting in enforcement, and advising the LGU on fishery matters. The members of the FARMC can include a representative from the accredited nongovernment organization, private sector and at least eleven fisherfolk representatives in each municipality/city which include representatives from the youth and women sector (Section 75, RA 8550). The eleven fisherfolk representatives consist of seven municipal fisherfolks, one fishworker and three commercial fishers. For bays, gulfs, lakes, rivers and dams bounded by two or more municipalities/cities, an Integrated Fisheries and Aquatic Resources Management Council can be created (Section 76, RA 8550).

Under RA 8550, LGUs can implement municipal water zoning as a strategy to effectively perform their responsibility to manage, conserve, develop, protect, utilize and dispose fish and fishery/aquatic resources within their respective municipal waters. As part of the LGUs' mandate to conserve, develop, and protect fishery resources within their municipal waters, LGUs in consultation with the FARMCs can enact an ordinance establishing fish refuge and sanctuaries (Section 81 of RA 8550). Fishery sanctuaries have biodiversity conservation functions though they are primarily established to help sustain fisheries production. Registered fisherfolk and cooperatives shall have preferential rights to the fishery privileges issued by the municipal/city government (Section 17, RA 8550). In addition, Section 21 of the Fisheries Code gives priority to resident municipal fisherfolk and their organizations/cooperatives in the use of municipal and demarcated fishery areas of the municipality. Fisherfolk can, directly or through the Fisheries and Aquatic Resources Management Council, notify the LGU that their preferential rights have been overlooked or disregarded and request that they be granted fishery privileges. If the LGU doesn't take any action, the concerned fisherfolk can file a case in court against the LGU and the concerned officials to assert their rights under RA 8550 and the Local Government Code. Section 16 of RA 8550 gives LGUs the jurisdiction over municipal waters, hence, the municipal and city governments have the exclusive authority to issue permits or licenses to fish within municipal waters and issue licenses for fishing gears. Before LGUs can issue licenses and permits, they need to pass an ordinance covering the procedures for granting permits, licenses and fishery privilege. The Fisheries Code has a long list of prohibited and approved activities based on fishing method employed, based on resource exploited, based on location of fishery activity, and other prohibited/regulated activities. The LGU may enact ordinances allowing or banning the use of certain fishing gear in accordance with procedure for local legislation in Section 48-59 of RA 7160. An LGU cannot impose a total ban on all types of fishing activities, but it can impose a closed area or closed season for a reasonable time period.

The roles and responsibilities of the LGU and the FARMC under the 1998 Fisheries Code for marine tenure and governance institutions are presented in Table 2 using five characteristics of 
property rights (exclusion, access/withdrawal, management, enforcement, alienation/transfer) [30].

An example can best illustrate the importance of these decentralization activities to comanagement in the Philippines. Prior to the 1991 LGC an ordinance to provide legal standing for a community-level marine protected area required approval by the secretary of the Department of Agriculture, which was a long and often unsuccessful procedure. With passage of the LGC, local municipalities had the legal right to approve an ordinance in support of a community-level marine protected area. Local government officials and fisher organizations now had the legal and administrative mandate to work cooperatively on coastal resource management. The establishment of FARMCs under the 1998 Fisheries Code, also strengthened co-management, as fishers now had authority to work cooperatively with the LGU on fisheries planning, management and enforcement.

The Fisheries Code was amended in 2015 through Republic Act 10654 to address IUU fishing and other purposes [31]. The amendment adopted the precautionary principle and called for managing fisheries and aquatic resources in a manner consistent with the concept of an ecosystem-based approach to fisheries management and integrated coastal area management in specific natural fishery management areas, appropriately supported by research, technical services and guidance from the State.

\subsection{National Integrated Protected Areas System Act}

RA 7586, an Act Providing for the Establishment and Management of National Integrated Protected Areas System (NIPAS), was enacted by Congress in 1992 to respond to the profound impact of human activities on all components of the natural environment particularly the effect of increasing population, resource exploitation, and maintaining the natural biological and physical diversities of the environment (Section 2) [32]. The NIPAS is the national system of classification and administration of all designated protected areas to maintain essential ecological processes and life-support systems, preserve genetic diversity, ensure sustainable use of resources found therein, and maintain their natural conditions to the greatest extent possible (Section 4). Briefly stated, the NIPAS Act allows the government to identify and segregate defined areas of land and/or water, and classify them as protected areas for various purposes. All national parks, wildlife reserves, and sanctuaries existing prior to 1992 were automatically incorporated into the NIPAS. A special management body called the Protected Area Management Board (PAMB) was then constituted, comprised of representatives of the national government, local governments concerned, and the private sector or affected communities, which was tasked with the formulation of management plans to ensure the conservation and sustainable management of the protected area. 
Table 2. Roles and Responsibilities for marine tenure and governance institutions under the 1998 Fisheries Code.

\begin{tabular}{|c|c|c|}
\hline \multirow[t]{2}{*}{ Tenure Rights } & \multicolumn{2}{|c|}{ Responsibilities of Devolved Tenure Governance Institutions 1998 Philippines Fisheries Code } \\
\hline & $\begin{array}{l}\text { Role of Local Government } \\
\text { Unit (Municipalities \& } \\
\text { Cities) }\end{array}$ & $\begin{array}{l}\text { Role of Municipal Fisheries and Aquatic Resources Management } \\
\text { Council (MFARMC) }\end{array}$ \\
\hline $\begin{array}{l}\text { Exclusion } \\
\text { Ability to exclude } \\
\text { outside fishers from } \\
\text { accessing their marine } \\
\text { resources or fishing in } \\
\text { their fishing grounds }\end{array}$ & $\begin{array}{l}\text { - Develops fisheries } \\
\text { ordinances that } \\
\text { determine who can fish in } \\
\text { municipal waters }\end{array}$ & $\begin{array}{l}\text { - Consults in the formulation of necessary mechanisms for inclusion } \\
\text { or exclusion in limiting entry into the municipal waters that shall be } \\
\text { most beneficial to the resident municipal fishers } \\
\text { - Recommends designation of portions of municipal waters for } \\
\text { fishery reserves or limited use, educational, research, and/or special } \\
\text { management purposes } \\
\text { - Consults on authorizing or permitting small and medium } \\
\text { commercial fishing vessels to operate within the } 10-15 \mathrm{~km} \text { area from } \\
\text { the shoreline in municipal waters }\end{array}$ \\
\hline $\begin{array}{l}\text { Access/withdrawal } \\
\text { Rights to access and } \\
\text { extract fish and other } \\
\text { marine resources }\end{array}$ & $\begin{array}{l}\text { - Maintains a registry of } \\
\text { municipal fishers }\end{array}$ & $\begin{array}{l}\text { - Submits to the local government the list of priorities for } \\
\text { consideration in determining priorities among those who will be } \\
\text { allowed to fish in municipal waters } \\
\text { - Assists the local government in maintaining a registry of municipal } \\
\text { fishing vessels by type of gear and other boat particulars }\end{array}$ \\
\hline $\begin{array}{l}\text { Management } \\
\text { Management and } \\
\text { maintenance practices } \\
\text { to help sustainably } \\
\text { use the resource and } \\
\text { achieve other goals } \\
\text { such as livelihood } \\
\text { support, food security, } \\
\text { and biodiversity } \\
\text { conservation }\end{array}$ & $\begin{array}{l}\text { - Develops fisheries } \\
\text { ordinances that } \\
\text { establishes } \\
\text { types and number of } \\
\text { fishing gears allowed for } \\
\text { use in municipal waters } \\
\text { - Develops CRM plans }\end{array}$ & $\begin{array}{l}\text { - Assists in the preparation of the Village (Barangay) and Municipal } \\
\text { Development Plan } \\
\text { - Recommends the enactment of municipal fishery ordinances } \\
\text { - Recommends the establishment of closed seasons for fisheries } \\
\text { management } \\
\text { - Advises the village/municipal legislative council on fishery } \\
\text { matters through its Committee on Fisheries } \\
\text { - Consults in the establishment of closed seasons for } \\
\text { municipal waters } \\
\text { - Consults in the establishment of catch ceiling limitations in } \\
\text { municipal waters for conservation and ecological purposes } \\
\text { - Consults on the determination of license fees for fishery activities } \\
\text { in municipal waters }\end{array}$ \\
\hline $\begin{array}{l}\text { Enforcement } \\
\text { Systems to enforce } \\
\text { rules, resolve } \\
\text { conflicts, and apply } \\
\text { sanctions }\end{array}$ & $\begin{array}{l}\text { - Enforces fishing } \\
\text { ordinances together with } \\
\text { Bureau of Fisheries and } \\
\text { Aquatic Resources, } \\
\text { Philippine National Police, } \\
\text { and other enforcement } \\
\text { entities }\end{array}$ & $\begin{array}{l}\text { - Assists the local government in the enforcement of fishery } \\
\text { laws, rules, and regulations in municipal waters }\end{array}$ \\
\hline $\begin{array}{l}\text { Alienation/transfer } \\
\text { Rights to sell, } \\
\text { mortgage or lease the } \\
\text { resources or area to } \\
\text { others }\end{array}$ & $\begin{array}{l}\text { - Leases use rights to } \\
\text { municipal waters }\end{array}$ & $\begin{array}{l}\text { - Consults on the designation/establishment of zones for the } \\
\text { construction of fish pens, fish cages, fish traps, and other structures } \\
\text { for the culture of fish and other fishery products }\end{array}$ \\
\hline
\end{tabular}

\subsection{Integrated Coastal Management}

Through Executive Order (EO 533), signed in 2006, Integrated Coastal Management (ICM) has been adopted by government as the national strategy for the sustainable development of the country's coastal and marine resources [33]. The EO also specifies the establishment of supporting mechanisms for its implementation, specifically the development of a National ICM program. The ICM program is a consultative process involving relevant agencies, sectors and 
stakeholders. The program also specifies the provision of direction, support and guidance to LGUs in the development and implementation of local ICM programs. While the program is a positive development in terms of creating more policy space for CBCRM, the Order is silent on the participation of the National Fisheries and Aquatic Resource Management Councils and local FARMCs in the planning. The FARMCs participation could have served to counterbalance the usual "top-down" mode of government planning.

\subsection{Indigenous peoples rights}

The 1987 Constitution of the Philippines guarantees resource control and rights of indigenous peoples (IP) to their ancestral lands [34,35]. Specifically, the Department of the Environment and Natural Resources DENR recognizes these rights. DENR issued Administrative Order No. 2 in 1993 to provide guidelines for issuing Certificates of Ancestral Domain Claim (CADC). The CADC gives rights to indigenous people to manage and to use the resources found within their domains in accordance with existing laws, to gain access to adequate and basic services, and to be able to plan their own future [36]. Domains include all lands and natural resources occupied or possessed by indigenous communities. These areas are also necessary to the economic, social, and cultural welfare of the indigenous group [37]. The CADC gives the indigenous group the preferential rights over the resources, but it does not formally give the indigenous group the exclusive use of the resources [38]. In order to apply for a CADC, indigenous groups must provide supporting evidence of a claim, such as burial sites and established resource use sites [29]. In accordance with the CADC, indigenous groups must also submit Ancestral Domain Management Plans (ADMP) that are "reflective of their needs and aspirations" [36]. The DENR's Administrative Order No. 34 (series of 1996) provided guidelines for formulating ADMPs where resources users of the ancestral domain would be required to abide by the plan's stipulations [38]. The ADMP is necessary to encourage sustainable resource use while promoting cultural integrity, strengthening ancestral claims, enhancing self-reliance and empowerment, and protecting traditional resource rights. An issue that is critically important in many parts of the Philippines, the CADC, through the ADMP, requires migrants entering ancestral lands to respect local management rules and governing bodies [39]. Although the CADC is not a title to the area, the CADC can serve as a strong basis to protect the community's tenure [37]. With time, indigenous groups can use their CADC as leverage to obtain a Certificate of Ancestral Domain Title (CADT), meaning full legal sanction of lands. A CADT refers to a title formally recognizing indigenous peoples' resource management rights and full ownership over their ancestral domains [40]. The NIPAS recognizes customary rights of indigenous peoples to their ancestral domains and supports perpetuation of their cultural practices and traditions. However, until 1997, the Philippines' constitution did not formally implement indigenous rights. The issuance of the CADT is slow and full of controversy. Also, the autonomy of the tribal councils continues to be undermined by national government priorities (e.g., opening up ancestral domains to mining explorations). The National Commission on Indigenous People (NCIP), the national agency representing the IPs, has been charged by some sectors for not providing enough services for the IP communities and for misrepresenting IP communities with regards to mining issues [41]. 
The Indigenous People's Rights Act (IPRA) was implemented in 1997 embodying a long struggle for the recognition of the rights of indigenous peoples to their ancestral domain land claim and cultural identity (Republic Act No. 8371, 1997). Massive land grabbing and development aggression in ancestral domains prompted coalition building of indigenous peoples, whose movement were often spread and isolated from each other. The advocacy campaign for the IPRA was ridden with controversy, such as the proper representation of diverse IP communities and the submission of their traditional claims and culture to the legal system.

Under this law, the NCIP was created as the primary government agency to carry out the objectives of the IPRA. The IPRA requires the State to not only respect, recognize, and protect the rights of IPs (Indigenous Peoples) but also to preserve and protect their culture, traditions and institutions (Section 29) [41]. The rights protected under IPRA encompass the right to claim ancestral domains that contain the physical environment and the cultural and spiritual bonds associated with the land, including sacred places and traditional fishing grounds [42]. This protection even extends to the traditional indigenous knowledge associated with natural resources (e.g., bioprospecting). The indigenous people can exclude others in exploiting the natural resources within their ancestral domain, including migrant settlers and organizations. Particularly, they are responsible for maintaining ecological balance of their resources [43].

The IPRA recognizes the property rights of indigenous cultural communities over their ancestral domains and ancestral lands. A traditional tribal council (composed of the tribal chief, council members, and spiritual advisers) is recognized by the law to draft policies on natural resource use and development plans in the ancestral domain. The tribal council can exercise their political muscle by invoking the use of their traditional tribal justice system as a sign of their cultural identity and autonomy from the national laws.

Although IPRA has gone through many controversies regarding its constitutionality and its adherence to the culture of the indigenous people, it provides opportunities for indigenous people to establish community-based property rights over ancestral waters, including marine waters. This has been done by the Calamianes Tagbanua in Northern Palawan. The management plan of the tribal council over their ancestral domain became more coherent after they were issued a CADT. The traditional beliefs and practices were enhanced when national laws recognized their mandate over the ancestral domain. It also strengthened the participation of the IPs in legal policy making, thus reducing conflicts between different stakeholders. The Tagbanua currently enjoy benefits from ecotourism while preserving their culture and conserving their ancestral land and waters.

As part of the Philippines compliance with the Convention on Biological Diversity, the Congress enacted Republic Act No. 7586, An Act Providing for the Establishment and Management of National Integrated Protected Areas System or the NIPAS Act. The Act sets aside both terrestrial and aquatic protected areas. Among other provisions of the Act is the recognition of ancestral rights to protected areas. Section 13 of the Act requires that members of concerned indigenous communities shall be consulted prior to the adoption of any regulations adopted by the DENR 
for the area, and other parts of the Act require their participation in all aspects of its management.

\subsection{Mangrove forests}

The agreement mechanisms (related to user and property rights) being used for mangrove management and conservation in the Philippines are the Community-Based Forest Management Agreement (CBFMA), Protected Area Community-Based Resource Management Agreements, Special Agreement in Protected Areas, Special Forest Land use Agreement, and Forest Land use Agreement for Tourism Purposes [44].

Mangrove forests are under the jurisdiction of the DENR (except areas released for conversion to fishponds). Executive Order 263 established community-based forest management (CBFM) as the national strategy for protection and regeneration of all forests and provides tenure instruments for fisherfolk communities to replant mangroves and sustainably use fishery resources according to an approved management plan. The CBFMA is a production-sharing agreement entered into by an organized community and the government to develop, utilize, manage and conserve specific portions of forest land consistent with the principles of sustainable development and pursuant to an approved Community Resource Management Framework Plan. CBFMAs empower communities to enter into agreements with private sectors and with any units of government for appropriate development and management projects in multiple use zone timberland areas as contained in the Community Resource Management Framework Plan in accordance with the provisions of Department Administrative Order 96-29, DENR and other pertinent policies, rules and regulations of the government of the Philippines. The Framework Plan defines the terms and procedures for access, use and protection of natural resources within CBFM area.

The Protected Area Community-Based Resource Management Agreement (PACBRMA) is entered into by the DENR representing the government and organized tenured migrant communities or interested indigenous peoples in protected areas and buffer zones (upland and mangroves). PACBMRAs have terms of 25 years and are renewable for another 25 years. This community-based program provides opportunities to organized tenured migrant communities and indigenous peoples to manage, develop, utilize, conserve and protect the resources within the protected areas and buffer zones. The tenure instrument is issued only within multiple use, sustainable use and buffer zones. However, the tenure holders may engage in protection and restoration activities in other allowable zones, such as restoration zones consistent with the Protected Area Management Plan. This management plan contains the rationale for protected area establishment, proposed boundaries including buffer zones and designation of management zones including buffer zones with purposes, strategies and allowable uses.

LGUs need to ensure and enforce an absolute ban on cutting of naturally grown mangrove stands (Fisheries Code, Forestry Code, and National Internal Revenue Code, amending specific provisions of PD 705). Local governments need to be vigilant against non-compliant fishpond lessees including those who do not pay appropriate fees to the BFAR and LGU, those who have 
abandoned or underutilize their lease areas, and those who have situated their ponds in unreleased areas.

\subsection{Foreshore}

The Philippine Fisheries Code defines foreshore land as is a string of land margining a body of water, the part of the seashore between the low water line usually at the seaward margin of a low tide terrace and the upper limit of wave wash at high tide usually marked by a beach scarp or berm. While the foreshore is always considered in the public domain, it can be leased to private land owners by the Department of Environment and Natural Resources under the Public Land Act for residential, commercial, and industrial purposes. With or without a foreshore lease agreement, however, uncontrolled coastal development, such as the construction of houses, walls, and other structures, is occurring in foreshore areas impinging on the preferential use rights of small-scale fishers in municipal waters [45]. Batongbakal [45] highlighted six major categories of problems with foreshore management including: classification, access, resource use, public safety, shoreline management and regulatory processes. Historically, the management of these areas have been neglected by national government leaving the issues to be addressed by local government. Legal reforms are necessary given the provisions of the 1987 Constitution which limits the modes of utilization of the country's resources and protects the rights of subsistence fisherfolk, especially of local communities, to the preferential use of the communal marine and fishing resources, both inland and offshore.

\subsection{Fisherfolk settlement}

The Philippine Fisheries Code has made explicit the reservation for and establishment of fisherfolk settlement areas near fishing grounds, to be done in coordination with concerned agencies of the government. However, this provision is weak due to several reasons. First, the law fails to provide the appropriate government agency to lead the implementation of the provision. Instead of the Department of Agriculture (referred to as "the Department" in the Fisheries Code), the more appropriate agencies are: the Department of Environment and Natural Resources which has jurisdiction over public lands; the Department of Agrarian Reform which verifies the inclusion or exclusion of the possible settlement areas in the Comprehensive Agrarian Reform Program; and the LGUs, which are vested with the authority to zone lands within their jurisdiction. Second, the section does not provide for the participation of fisherfolk in the establishment of settlement areas. Third, the fisheries code fails to allocate the necessary financial resources to implement the provision. Fourth, the law fails to provide details on how this right will be enforced. Fifth, the provision fails to establish a security of tenure for the fisherfolk because it deprives them the bundle of rights associated with ownership of the land. Finally, the law does not recognize that the area of settlement shall be the same area where fishers are currently settled.

\subsection{Marine protected areas}


Marine protected areas (MPAs) such as reserves, sanctuaries and parks are used to protect particular well-defined areas and critical habitats [46]. MPA is a broad term for sites which boundaries have been established in order to provide some level of management. Many MPAs are managed through a community-based or co-management governance arrangement.

The authority to establish and manage an MPA is held by three jurisdictions - local government, DENR and the BFAR. Both national government agencies have responsibilities for protecting marine environments. Laws for protected areas are the National Fisheries Act of 1998 (RA 8550) and the National Integrated Protected Areas System Act of 1992 (NIPAS-RA 7586).

LGUs utilize MPAs as a coastal management and fisheries management tool. Within their regulatory boundaries, LGUs are able to establish sanctuaries, limit access to marine resources, prescribe zones for different uses, as well as collect taxes or fees associated with the use of the municipal waters. LGUs do not require the approval of national government agencies to establish municipal reserves or sanctuaries.

A typical MPA or fish sanctuary in the Philippines consists of a core zone (typically a strictly notake zone) and a buffer zone (usually a limited take zone).

The establishment of a managed marine area is always done with the participation of the community. Community ownership of the intervention is a very important element for the sustained implementation and, ultimately, the success of marine managed or protected area initiatives. Community ownership may not be achieved through a prescribed set of interventions or patented steps but it helps to have elements in place to ensure higher chances of success.

\subsection{Autonomous Region in Muslim Mindanao}

The law governing the management, development, protection and disposition of fisheries and aquatic resources in the Autonomous Region in Muslim Mindanao (ARMM) is the Muslim Mindanao Autonomy Act 86 also known as the ARMM Aquatic and Fisheries Code of 1999 [47]. The Framework Agreement on the Bangsamoro in Muslim areas of Mindanao would provide for exclusive use rights to utilize and manage natural resources to the Bangsamoro. This is generally considered to be sovereignty issue more than a property rights issue.

\section{Examples of implementation of the national laws and policies to support marine tenure}

Two examples of the impact of the national laws and policies discussed above are discussed to illustrate their impact on securing marine tenure in the Philippines. These are Hinatuan to illustrate the Local Government Code, the Fisheries Code, NIPAS and Integrated Coastal Management [48] and the Tagbanua to illustrate indigenous people's rights [49]. 
Hinatuan, a municipality located in northeastern Mindanao, faced continuing threats to its coastal and marine resources including mangrove clearing for fishpond building, illegal fishing and overfishing, and poaching inside declared marine sanctuaries [48]. To address these threats, the Hinatuan Municipal Fisheries Ordinance (MFO) was approved in June 2004. Among other things, the MFO provided for and put in place the following policies and management systems:

- A participatory coastal governance regime that mandates the municipal government to manage, protect, and regulate the use of coastal and marine fishery resources, consult with the Municipal Fisheries and Aquatic Resources Management Council (MFARMC), and delegate its powers to the Barangay Fisheries and Aquatic Resources Management Councils (BFARMCs), NGOs, and fisherfolk organizations in enforcing fishery and environmental laws.

- Exclusive use of Hinatuan's coastal and fishery resources is granted to Hinatuan residents, with preferential rights to marginal and subsistence fisherfolk. Prohibition of commercial fishing within municipal waters. Prohibition of fishing activities within declared marine sanctuaries and overfished areas.

- Regulation of all fisheries activities in municipal waters, including aquaculture activities, through the imposition of fees, issuance of licenses, leases and permits, and registration of fishers, fishing boats, and fishing gears.

- Zonation of coastal waters, delineating areas reserved for navigational lanes, construction of various fishing structures and apparatus, economic zones, and marine protected areas or marine sanctuaries. Eight established marine sanctuaries with a total area of 476 ha have been included and classified under the said zonation scheme.

- Prohibition of specific fishing gears, including fine mesh nets, triple nets, baling (beach seine), and sud-sud (push net) within municipal waters. Fishing through the use of explosives, poisonous and noxious substances or chemicals, and electricity, are declared illegal.

Claims and preferential rights over fisheries resources within Hinatuan's municipal waters have strengthened through the years since the local people's organization, Ladies in United Movement Onward to Development (LUMOD) started implementing resource management measures. The approval of the MFO and the municipal government's support to LUMOD and their enforcement groups further bolstered the residents' perception of such claims. Also, the right to manage coastal resources is not only geared towards protecting and sustaining the fishers' main source of livelihoods: there is a clear awareness that current management efforts would also benefit succeeding generations in the form of a healthy and improved coastal environment.

The Tagbanua are an indigenous people who live on Coron Island in Palawan [49]. In 1985, the indigenous communities established the Tagbanua Foundation to address the resource-use issues in the area and applied for a Community Forest Stewardship Agreement (CFSA) with the Department of Environment and Natural Resources (DENR). In 1993, DENR issued a Department Administrative Order 02 (DAO 02-93) that provides the rules and regulations for recognizing 
and awarding a Certificate of Ancestral Domain Claims (CADC), by which the nation recognizes the inherited and preferential rights of indigenous communities to extract, exploit, manage and protect their delineated ancestral territory.

The Tagbanua formulated an Ancestral Domain Management Plan (ADMP) governing all claimed territories. In 1998, DENR approved the CADC of the Tagbanuas covering 22,284 ha that include the entire island and a portion of the seas surrounding it. The passage of the Indigenous People's Rights Act (IPRA) or Republic Act 8371 in 1997 became a milestone in establishing a comprehensive system for protecting the rights of the indigenous people's (IP). This law recognizes three basic rights:

- the rights of ownership of indigenous communities to their ancestral lands and bodies of water

- the right to traditional resource management practices

- the right to secure a free, prior informed consent (FPIC) from the community in advance of the implementation of any project or initiative within areas identified as traditional territories.

Such ownership of resources by indigenous peoples is basically private but communal and cannot be disposed of or sold. With recognition of their rights, the indigenous people have been able to define an appropriate management system in their own terms.

5. Non-governmental organizations and project initiated marine tenure Several initiatives on marine tenure and rights-based management have been undertaken in recent years by non-governmental organizations and a foreign-funded fisheries project in the Philippines.

\subsection{Rare TURF-reserve}

Rare, a US-based NGO with an office in the Philippines, is implementing the Fish Forever program. The foundation of the program is establishing TURF-reserves in selected sites in the country. Area-based fishing rights, commonly referred to as Territorial Use Rights for Fishing (TURFs) programs, allocate secure, exclusive fishing privileges within a specified marine area to a group case or an individual. TURF reserves are TURFs paired with no-take reserves, which are areas where no fishing is permitted.

There is no legal basis for TURF-Reserves in the Philippines. Because municipalities are free to manage their municipal waters and to define user rights or no take zones and respective policies, any TURF reserve approach would have to be implemented over a municipal ordinance. For the TURF-Reserve to work, it will be important to know who is fishing in which boats, what is being fished, how much, when, and where. Enforcement remains the biggest challenge. In many cases, ordinances cannot be implemented because the municipality has no 
capacity or budget to employ officers to enforce it. The probability of success for implementing TURF reserves thus depends on the enabling environment and enforcement of the LGU.

It has been suggested by Rare that the primary policy areas important in the advancement of coastal fisheries and rights-based management in the Philippines pertain to how well the local governments cooperate among themselves in any given area of the country. Since each municipal/city government has its own set of regulations to manage its own areas of jurisdiction, it is important that these are synchronized with other local governments in the same management area. Also, since national law does allow for enforcing areas of access by municipal/city jurisdiction, this requires that groups or clusters of LGUs have a common understanding or agreement and thus legal policies on how they will work together to manage an area. The most successful small scale fisheries management in the Philippines have occurred where LGUs have banded together and formed management clusters with common local ordinances and binding agreements within the cluster. The Fisheries Code reinforces the need for this cooperation but it does not guarantee that it will occur. In this regard, the regional offices of BFAR can play more of a role in the facilitation of LGUs working together on common fisheries management issues.

\subsection{Locally managed marine area (LMMA)}

The Philippines is a member of the locally managed marine area (LMMA) Network [50]. The Philippine LMMA (PhiLMMA) Network has member sites in Zambales, Batangas and Romblon. Two local NGOs, SIKAT and Center for Empowerment and Resource Development are the LMMA Network members in the Philippines. In the Philippines, the LMMA Network's approach of establishing locally managed marine areas and using community-based adaptive management is often viewed as part of, if not similar to, the familiar CBCRM approach, given the key principles behind both concepts and the history of CBCRM in the country.

A LMMA is an area of nearshore waters and its associated coastal and marine resources that is largely or wholly managed at a local level by the coastal communities, land-owning groups, partner organizations, and/or collaborative government representatives who reside or are based in the immediate area. Communities typically set aside at least part of an LMMA as a notake reserve (oftentimes referred to as an MPA, but with a different meaning than the formal definition above) or impose certain gear, species, or seasonal restrictions to allow habitat and resources to recover from fishing pressure, or to sustain or increase fish catch. An LMMA can vary widely in purpose and design; however, two aspects remain constant: 1) a well-defined or designated area; and 2) substantial involvement of communities and/or local governments in decision-making and implementation. In using an LMMA approach, some coastal communities are reviving traditional practices that have been used as part of their culture for many generations. Others are using more modern ideas introduced from outside. Some use a combination of both. 
The Learning Framework of the LMMA Network takes into account the importance of governance in LMMA management; with the term 'governance' refering to the particular set of institutions, rights, and rules operating within and guiding a society.

\subsection{Preferential use rights and marine spatial planning in municipal waters}

Three USAID funded projects, the Coastal Resource Management Project, the Fisheries Improvement for Sustainable Development (FISH) project, and the Ecosystems Improved for Sustainable Fisheries (ECOFISH) project, have provided technical assistance to LGUs in delineating municipal waters and conducting marine spatial planning (MSP) to support preferential use and tenure rights for small-scale fishers (It should be noted that all projects are now completed) [51]. In fisheries management, MSP or at least its fisheries use zoning component, is an effective tool for consolidating the range of management interventions, particularly in relation to the various marine spatial uses. Zoning as a tool does not replace any of the coastal and marine management tools already in place. In fact, it has to be highlighted that MSP or its fisheries use zoning component will only attempt to consolidate the various management initiatives by ensuring that the spatial scale is considered. In the coastal and fisheries use context, zoning is meant to reduce conflicts among various capture fisheries activities, between capture fisheries and other sea uses (maritime, tourism and mariculture), and between human activities and marine environment, particularly in key habitats such as mangrove forests, seagrass beds and coral reefs.

\section{Discussion}

In the Philippines, the LGU together with the associated MFARMC (as a multi-stakeholder body) form the primary governance structures through which marine tenure rights (exclusion, access/withdrawal, management, enforcement, and alientation/transfer) in municipal waters are allocated and exercised. The MFARMC together with the LGU have the responsibility to uphold the constitutional and national legal rights of small-scale fishers to the exclusive use of municipal waters. Few MFARMCs are truly representative of the small-scale fishers interests and are minimally effective. The erosion of tenure rights has occurred sometimes with the approval of a MFARMC whose members can be hand-picked by LGU executives. In the absence of capable and transparent local institutions, special interests can threaten tenure security. This highlights the importance of promoting full and effective participation in community governance structures.

It has not been easy for the LGUs to live up to the provisions of all this new legislation and initiatives for marine tenure in the Philippines. While many mayors have welcomed this new authority, they also realized that they must rely less on the national government for support. Many local governments were not prepared or were unaware of their new roles, limited resources were made available to them from the national government for the transition, and it has taken them awhile to adjust to the new authority that they now have. Many have not done anything, while some have actively engaged in supporting fisher organizations and local 
management measures. In this context, the new administrative structure has bred success in locations that could not have been reached by national programs. Experience has shown that the mere promulgation of legislation and polices to control resource use practices cannot in itself lead to sustainable management of fisheries resources. These efforts must be combined with capacity building and education for all stakeholders.

In a paper by Vera, Cabaces and Reyes [48], they state that:

"Although community-based coastal resource management is a popular approach, it would not be correct to say that the Philippines has a community right regime. The Fisheries Code provides several opportunities as starting points for a community rights regime such as decentralization of the jurisdiction of municipal waters to LGUs, creation of the MFARMC, prioritization of resident fishers in the use of municipal waters, recognition of traditionally marginalized sections of the fisherfolk sector (i.e., women and youth). However, there is still much more work for fisherfolk communities to realize a community-based rights regime. LGUs would need to pass fishery ordinances that would limit the pressure from migrant fishers to be able to successfully manage municipal waters. Strong fisherfolk organizations or representatives must fully engage the LGU in order to transcend the recommendatory nature of the MFARMCs. In addition, further harmonization between the functions of the BFAR, the DENR and the LGUs needs to be done in order to develop more efficient, decentralized and devolved governance systems of the coastal zone."

Vera et al. [48] go on to say that the community-based approach pushed the local government to recognize that fisherfolks are key partners of LGUs in serving their constituents. This recognition, including the development of capacities and knowledge in fisheries management and community development, has built up the confidence of the fisherfolk and empowered them to voice out their vision and issues. This empowerment is greatly recognized by fisherwomen who are members of the organizations. Not only do they get the opportunity to participate in activities outside the household, their knowledge and skills as leaders are recognized by others. Their role in development is more valued.

Overall, however, those involved in fisheries conservation and management in the Philippines feel that the new authority has been a positive step towards supporting marine tenure and sustainable management of fisheries resources in the country [52-54]. In a review of Philippine community based natural resource management (CBNRM) done for the Ford Foundation, it was concluded that CBNRM remains the nation's best hope for sustainability [55]. The editors, Gollin and Kho, conclude that government, specifically local government, needs to become integral to community-based management. They posit a multistakeholder body attached to the LGU as the form of management most likely to be able to support CBNRM's goals of local control and local benefit. This is felt to be the most viable form of community-based institution. They find that rather than being an easily identifiable 'community' to which one can turn over management, the reality is that social boundaries of most organized communities don't equate with the local people's sense of who 'the community' is. Vesting particular local organizations 
with the sole rights to benefits is therefore often and understandably a source of local conflict and does not provide the needed link to sustainability required by CBNRM's premise.

Gollin and Kho [44] conclude that the people's organization model of community that prevails in the Philippines CBNRM needs to be modified. The study found the importance of preexisting social solidarity is needed to accomplish natural resource management. Any attempt to externally initiative community natural resource management cannot hope to duplicate this level of internal cohesion. Also the diversity of resource interests significantly increase the difficulty of internal cohesion. They suggest a two track approach to community and property rights - one that distinguishes two different categories of rights to be transferred, use rights and decision-making rights, and two different 'community' holders of those rights. The allocation of use rights should be given to the resource users and made secure. The decisionmaking rights, the power to decide how resource are used and who may use them, should be vested in community-based institutions, a multi-sectoral body formally attached to a LGU.

While both ECOFISH and Rare are supporting security of marine tenure rights, they are not explicitly considering the entire bundle of rights. By providing assistance to LGUs for fisher registration and gear licensing, both projects are securing the rights of fishers to access and extract marine and fishery resources from municipal waters. Secure access to fishery resources needs to be coupled with appropriate support for legislation that enforces the exclusion of fishers from other municipalities from fishing. Rare is strengthening community-based management of marine reserves to provide greater incentives. Under this approach, managed access zones are being established around the marine reserves where access/withdrawal rights are provided only to those fishers enforcing the marine reserve. In both projects alienation/transfer rights are not explicitly considered, thus increasing the potential for other rights to be eroded. For example, in Coron, the expansion of leases of municipal water areas to commercial operators of pearl farms was successfully opposed by local fishers; however, existing leases provide no compensation for lost fishing grounds.

\section{Conclusions}

The Philippines has a strong foundation, at both national and local government levels, to secure tenure rights to fisheries resources for small-scale fishers and meet its commitments under the UN FAO Voluntary Guidelines on Securing Sustainable Small-Scale Fisheries in the Context of Food Security and Poverty Eradication (SSF Guidelines). There is a strong legal framework for protecting tenure rights in the Philippines. The exclusive right of Filipinos to use fishery resources and preferential use rights for subsistence is enshrined in the Philippine Constitution and other national laws and policies. Management of local fishery resources is considered not only a responsibility but also a right. Though this right is more enthroned to the LGUs rather than fisher communities by the Fisheries Code, it is evident that the spirit of the law is to devolve powers to manage the coastal resources to the fishers. These instruments encourage fishers to take charge of resource management planning and implementation. Tenure rights are

important to ensure that fisher communities obtain permanent, exclusive rights over the resources in a specific area, that fickle politics or legislation will not eventually deprive them of the long-term benefits of their management efforts. Not all LGUs are recognizing and protecting 
legitimate tenure rights. While all LGUs are required to have a Coastal Resources Management (CRM) plan including a fisheries management plan which recognizes tenure rights, there may be no implementation. Much of the recognition depends upon the priorities of the mayor.

There is an opportunity to support and strengthen marine tenure insitutions, (people's organizations, barangay, MFARMCs, as well as various national and local government offices and Sagunian Bayan) so that they can support the fullness of their mandate for marine tenure; develop effective co-management arrangements; consider the vision for sustainable management of local waters; and provide the administrative, legislative, and other mechanisms to recognize tenure rights. While marine tenure considerations often focus on the tenure rules governing rights and responsibilities, it is critical to strengthen marine tenure governance institutions that design the tenure arrangements and therefore create these rules. By providing consistent support to strengthening governance bodies (at barangay and municipal levels), an effective institutional modality can be created through which multiple objectives can be pursued over time such as biodiversity conservation, food security, eradication of extreme poverty, and climate change resilience. Focusing not only at the municipal but also at the barangay level builds sustainability into the tiered tenure arrangements since communities have the greatest commitment to support their ongoing welfare and well-being.

A review and analysis of the capacity and record of accomplishment of key tenure governance institutions involved in co-management in the Philippines, including national and local government entities, MFARMCs, indigenous peoples groups, and people's organizations, is needed to identify gaps, challenges and strategies to strengthen responsible governance of tenure in the context of the existing national legal and policy framework. Finally, the problem of how NIPAS intersects with the Fisheries Code, in terms of the strength of the NIPAS mandate vis-à-vis the LGU's authority over municipal waters and the preferential use rights of small-scale fishers are key issues that needs to be revisited and clarified.

\section{Acknowledgements}

We thank Stephen Brooks, Senior Resource Governance Advisor, Office of Land and Urban, Bureau for Economic Growth, Education and Environment, US Agency for International Development for his leadership and expertise on this project. This publication was based on independent research on the Tenure and Global Climate Change program that was supported by the United States Agency for International Development by Tetra Tech, through a Task Order under the Strengthening Tenure and Resource Rights Indefinite Quantity Contract (USAID Contract no. AID-OAA-TO-13-00016). This publication does not necessarily represent the views of USAID or the United States Government.

\section{References}

[1] FAO, Governance of tenure: finding common ground, Voluntary guidelines on responsible governance of tenure of land and other natural resources, Natural Resources Management and Environment Department, FAO, Rome, 2011. p. 6. 
[2] C.A. Courtney, N.J. Jhaveri, Marine Tenure and Small-scale Fisheries: A Sourcebook on Good Practices and Emerging Themes, USAID Tenure and Global Climate Change Program, Washington, DC, 2017.

[3] D. Bromley, Environment and Economy: Property Rights and Public Policy, Blackwell, Cambridge, Massachusetts, 1991.

[4] S. Aggarwal, M.S. Freudenberger, Tenure, Governance, and Natural Resource Management: Contributions to USAID Development Objectives, Property Rights and Resource Governance Briefing Paper 9, U.S. Agency for International Development, Washington DC, 2013.

[5] A. Charles, Governance of marine tenure in small-scale fisheries: key considerations, Land Tenure J. 1-13 (2013) 9-38.

[6] A. Charles, Rights-based fisheries management: the role of use rights in managing access and harvesting, in: K.L. Cochrane, S.M. Garcia (Eds.), A Fishery Manager's Guidebook, WileyBlackwell, Oxford, England, 2009.

[7] FAO, Voluntary Guidelines for Securing Sustainable Small-Scale Fisheries in the Context of Food Security and Poverty Eradication, FAO, Rome, 2015.

[8] USAID, Sustainable Fisheries and Responsible Aquaculture: A Guide for USAID Staff and Partners. Washington, DC, 2013.

[9] A.G.M. La Viña. Management of fisheries, coastal resources and the coastal environment in the Philippines: Policy, legal and institutional framework, Policy, Legal Inst. Stud. Work. Pap. No. 5, International Center for Living Aquatic Resources Management and Swedish International Development Agency.

[10] B.N.V. Kalagayan, Philippine initiatives in marine coastal conservation, Lundayan II (1) (1991) 2-7.

[11] M.D.G. Lopez, Notes on traditional fisheries in the Philippines, in: K. Ruddle, R.E. Johannes (Eds.), The Traditional Knowledge and Management of Coastal Systems in Asia and Pacific, UNESCO, Jakarta, 1983.

[12] E. Ferrer, Prospects for territorial use rights in the Lingayen Gulf area, in: G. Silvestre, E. Miclat and T.E. Chua (eds.), Towards sustain able development of the coastal resources of Lingayen Gulf, Philippines. ICLARM Conference Proceedings 17, ICLARM, Manila, Philippines, 1989.

[13] M. Mangahas, Traditional marine tenure and management in ASEA N, in: G.R. South et al. (eds), Traditional Marine Tenure and Sustainable Management of Marine Resources in Asia and 
the Pacific: Proceedings of the International Workshop Held at the University of the South Pacific, Suva, Fiji, 1994.

[14] A. Cruz-Trinidad, Socioeconomic and bioeconomic performance of Philippine fisheries in the recent decades, in: G. Silvestre, L.R. Garces, I. Stobutzki, M. Ahmed, R.A. Valmonte-Santos, C. Luna, L. Lachica-Aliño, P. Munro, V. Christensen, D. Pauly (Eds.), Assessment, Management and Future Directions for Coastal Fisheries in Asian Countries, WorldFish Center, Penang, Malaysia, 2003, pp. 543-576.

[15] A. Heinan, N. Gonzales, Fisheries Management and Development in the Philippines: Constraints and Possibilities, Community Extension and Research Development, Quezon City, Philippines, 1993 (Unpublished paper).

[16] R. Agbayani, Some indigenous cultural traditions in the Philippines: their implications of environmental conservation, J. New Think. Philipp. Soc. Issues 2 (2) (1993).

[17] M.L.D. Palomares, D. Pauly,, Reconstructed marine fisheries catches of the Philippines, 1950-2010, in: M.L.D. Palomares, D. Pauly(eds.), Philippine Marine Fisheries Catches: A Bottom-up Reconstruction, 1950 to 2010, Fisheries Centre Research Report 22(1), Fisheries Centre, University of British Columbia Vancouver, Canada, 2014, pp. 129-138.

[18] R.M. Briones, Eating for a lifetime: filling the policy gaps in Philippine fisheries, Asian J. Agric. Dev. 4 (1) (2007) 25-39.

[19] Quicho, R.F.N. Jr., G.T. Mislang, A.S.P. Batay-an, Access to resources in coastal waters for municipal fisherfolk, Paper Presented at Pangisdaan ni Juan: A Forum on Access to Resources in Coastal Areas, 11 November 1999. University of the Philippines College of Law, Quezon City, Philippines, 1999.

[20] J.R. Garcia. Equitable access and preferential use of municipal waters by municipal fisherfolk, p. 175-179, in: DA-BFAR (Department of Agriculture-Bureau of Fisheries and Aquatic Resources), In Turbulent Seas: The Status of Philippine Marine Fisheries, Coastal Resource Management Project, Cebu City, Philippines, p. 378.

[21] R.S. Pomeroy, M.B. Carlos, Community-based coastal resource management in the Philippines: a review and evaluation of programs and projects, 1984-1994, Mar. Policy 21 (1997) 445-464.

[22] R. Pomeroy, Governance of tenure in capture fisheries in Southeast Asia, Land Tenure J. 1 (2013) 39-65.

[23] DENR, DA-BFAR, DILG, Philippine Coastal Management Guidebook Volume 1: Coastal Management Orientation and Overview, Coastal Resource Management Project of the 
Department of Environment and Natural Resources, Cebu City, Philippines, Supported by the United States Agency for International Development, 2011, p. 58.

[24] P.G. Sajise, Community-based resource management in the Philippines: perspectives and experiences, Paper Presented during the Training Course in Co-management of Living Coastal Resources in ASEAN: Theory, Practice and Implications for Vietnam, Ministry of Fisheries, Hanoi, Vietnam, 1995.

[25] C.B. Serna, Community-based resources management: perspectives, experiences and policy issues, in: F. Fellizar (Ed.), Community-based Resource Management: Perspectives, Experiences and Policy Issues, University of the Philippines, College, Laguna, Philippines, 1993.

[26] R. de Sagan, The Local Government Code and Its Provisions on Fisheries, Bureau of Fisheries and Aquatic Resources, Quezon City, Philippines, 1992.

[27] M.S. Tabunda, M.M. Galang, A Guide to the Local Government Code of 1991, Mary Jo Educational Supply, Manila, 1992.

[28] CEPF (Critical Ecosystem Partnership Fund), Ecosystem Profile - The Philippines Hotspot, Conservation International, Arlington, VA, USA, 2001.

29] Republic Act No. 8550, The Philippines Fisheries Code of 1998. 〈www.lawphil.net/statutes/repacts/ra1998/ra_8550_1998.html〉.

[30] D. Bromley, Environment and Economy: Property Rights and Public Policy, Blackwell, Cambridge, Massachusetts, 1991.

[31] Republic Act No. 10651, An Act to Prevent, Deter and Eliminate Ilegal, Unreported and Unregulated Fishing Amending Republic Act No. 8550.

〈www.lawphil.net/statutes/repacts/ra2015/ra_10654_2015.html〉.

[32] National Integrated Protected Areas System Act, Republic Act No. 7586.

〈www.lawphil.net/statutes/repacts/ra1992/ra_7586_1992.html〉.

[33] Integrated Coastal Management, Executive Order No. 533.

〈www.officialgazette.gov.ph/2006/06/06/executive-order-no-533-s-2006/〉.

[34] R.L. Bryant, Non-governmental Organizations and Governmentality: "Consuming" Biodiversity and Indigenous People in the Philippines, Political Stud. 50 (2002) 268-292.

[35] M.E. Calcari Indigenous marine tenure in a common-pool framework: a Philippine case study, Master's Project Submitted in Partial Fulfillment of the Requirements for the Master of Environmental Management Degree in the Nicholas School of the Environment of Duke University, 2004. 
[36] DENR, Annual Report, Department of Environment and Natural Resources (DENR), Quezon City, 1996.

[37] E.F.L. Pinto, Addressing resource management concerns of the indigenous communities in Palawan, Cult. Surviv. Q. 20 (1) (1996).

[38] D. Dalabajan, The Healing of a Tagbanua Ancestral Homeland, Environmental Legal Assistance Center, 2000, 〈http://www.cbcrmlearning.org/Special\%20pages/Books_files/Hope\%20pdf/Case\%2010.pdf〉.

[39] J.F. Eder, Indigenous Peoples, Ancestral Lands and Human Rights in the Philippines. Cultural Survival Quarterly, 18(2), Department of Environment and Natural Resources (DENR), 1996, Guidelines on the Management of Certified Ancestral Domain Claims, Manila: DENR, 1994.

[40] F.M. Claver. Indigenous Peoples' legal systems: examples, experiences and governmental, administrative and judicial measures to accommodate customary law in national systems of justice, Paper Presented at the Expert Seminar on Indigenous Peoples and the Administration of Justice, Office of the United Nations High Commissioner for Human Rights and Universidad Nacional de Educación a Distancia, 〈http://www.unhchr.ch/indigenous/bp12.doc〉.

[41] First Peoples Worldwide, Philippines: Summary of Land Rights.

〈http://www.firstpeoples.org/land_rights/Philippines/summary.htm〉.

[42] L. Rimban, Philippines: Legal Claim Opens Doors for Indigenous Islanders, 〈http://www.mydestiny.net/ domeng/resources_coronpcij.html〉.

[43] Protected Areas Wildlife Bureau, The First Philippine National Report to the Convention on Biological Diversity, Department of Environment and Natural Resource, Republic of the Philippines, 1998.

[44] D.M. Melana, J. Atchue III, C.E. Yao, R. Edwards, E.F. Melana, H.I. Gonzales, Mangrove Management Handbook, Department of Environment and Natural Resources, Manila, Philippines through the Coastal Resource Management Project, Cebu City, Philippines, 2000 (96 pp).

[45] Jay L. Batongbakal, A Crowded Shoreline: Review of the Philippines' Foreshore and Shore Land Management Policies, Prepared for the Coastal Resource Management Project of the Department of Environment and Natural Resources Supported by the United States Agency for International Development, 2001., p. 39.

[46] A. White, P. Alino, A. Memeses, Creating and Managing Marine Protected Areas in the Philippines, Fisheries Improved for Sustainable Harvest Project, Coastal Conservation and 
Education Foundation Inc., and University of the Philippines Marine Science Institute, Cebu City, Philippines, 2006 (83pp).

[47] Muslim Mindanao Autonomy Act 86 also Known as the ARMM Aquatic and Fisheries Code of 1999. 〈Oneocean.org/download/db.files/mmaa\%2086.pdf).

[48] C.R. Vera, Cabaces, L. Reyes. Case study: the Philippines, Paper Presented at the International Collective in Support of Fishworkers (ICSF) Workshop: Asserting Rights, Defining Responsibilities: Perspectives from Small-scale Fishing Communities on Coastal and Fisheries Management in Asia, 3-5 May 2007, Siem Reap, Cambodia.

[49] R. Capistrano, Reclaiming the ancestral waters of indigenous peoples in the Philippines: the Tagbanua experience with fishing rights and indigenous rights, Mar. Policy 34 (2010) 453-460.

[50] A. Mercado, Making Governance Work for Marine Conservation. Lessons from the Philippines: Zambales, Batangas and Romblon, Philippine Locally-Managed Marine Area Network, Inc. L. Mendoza Building, Kamuning Road, Quezon City, Philippines, 2011.

[51] N. Armada, Fisheries refugia, marine protected areas, and fisheries use zoning: some of the tools used in managing fisheries in the Philippines, J. Mar. Biol. Ass. India 56 (1) (2014) 77-84.

[52] R.N. Tagarino, Local Government Initiatives in Fishery Resources Management: Its Implications on Sustainability, Center for Policy and Development Studies, University of the Philippines, Los Banos, College, Laguna, Philippines, 1995.

[53] F.P. Fellizar, R.G. Bernardo, A.P.H. Stuart, Analysis of Policies and Policy Instruments Relevant to the Management of Fisheries/aquatic Resources with Emphasis on Local Level Issues and Concerns, SEAMEO Regional Center for Graduate Study and Research in Agriculture, Los Banos, College, Laguna, Philippines, 1997.

[54] C. Courtney, A.T. White, E. Anglo, Coastal Resource Management in the Philippines: Lessons and Directions for Sustainability, Coastal Resource Management Project, Tetra Tech EM Inc. and the Asian Development Bank, Cebu City, Philippines, 2000.

[55] K. Gollin, J. Kho (Eds.), After the Romance: Communities and Environmental Governance in the Philippines, Ateneo de Manila University Press, Quezon City, Philippines, 2008. 